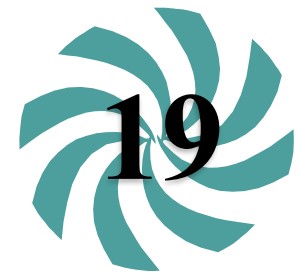

Tecnociencia, Vol. 23, $\mathrm{N}^{\circ} 1: 351-363$

Enero-Junio 2021

\title{
EVALUATION OF ANTIBACTERIAL PROPERTIES OF THREE PANAMANIAN PLANTS AGAINST MULTI-DRUG RESISTANT BACTERIA
}

\author{
1,2 Ramy Jhasser Martínez, (iD 1,3 Lilia Chérigo, \\ ${ }^{4}$ Nivia Ríos
}

${ }^{1}$ Laboratorio 107, Laboratorios científicos. Vicerrectoría de Investigación y Postgrado. Universidad de Panamá. chery826@hotmail.com. ${ }^{2}$ Laboratorio de Estudios Biológicos de Artrópodos, Vicerrectoría de Investigación y Postgrado, Universidad de Panamá. ramymartonez1009@gmail.com;. ${ }^{3}$ Departamento de Química Orgánica. Facultad de Ciencias Naturales, Exactas y Tecnología. Universidad de Panamá. ${ }^{4}$ Departamento de Microbiología y Parasitología. Facultad de Ciencias Naturales, Exactas y Tecnología. Universidad de Panamá. toxogondii@gmail.com

\begin{abstract}
The increased resistance of pathogenic bacteria to traditional therapy has forced the implementation of different therapies. The consequent use of more than one antibacterial drug can increase toxicity problems, an undesirable situation, especially when it comes to therapy for immunosuppressed patients. Bacterial resistance to different drugs is a war between "humans and bacteria". For this reason, it is important to keep looking for new alternatives for the treatment of pathogenic bacteria. In this study, we determined the antimicrobial activity of methanolic extracts of Lippia graveolens, Sphagneticola trilobata and Gliricidia sepium against four pathogenic bacteria: Pseudomonas aeruginosa, Escherichia coli, Klebsiella pneumoniae and Staphylococcus aureus. Pseudomonas aeruginosa was the strain most affected by antagonistic activity of all the extracts evaluated, followed by E. coli and S. aureus. We found that $S$. trilobata was the plant with the highest activity. We carried out tests mixing extracts $(1: 1)$ from different parts of each plant, where there was antagonistic and synergistic activity. These results are very promising, since these bacteria are currently being studied for their high resistance mechanisms to a wide variety of antibiotics.
\end{abstract}

\section{KEYWORDS}

antimicrobial, Gliricidia sepium, Sphagneticola trilobata, Lippia graveolens, inhibitory effect. 


\title{
EVALUACIÓN DE LAS PROPIEDADES ANTIBACTERIANAS DE TRES PLANTAS PANAMEÑAS CONTRA BACTERIAS MULTIRRESISTENTES
}

\begin{abstract}
RESUMEN
El aumento de la resistencia de las bacterias patógenas a la terapia tradicional ha forzado la implementación de diferentes terapias. El consiguiente uso de más de un antibacteriano puede aumentar los problemas de toxicidad, y esta situación no se desea, especialmente cuando se trata de terapia para pacientes inmunosuprimidos. La resistencia a diferentes drogas por parte de las bacterias es una guerra entre "humanos y bacterias". Por esta razón, es importante seguir buscando nuevas alternativas para el tratamiento de bacterias patógenas. En este estudio, determinamos la actividad antimicrobiana de extractos metanólicos de Lippia graveolens, Sphagneticola trilobata y Gliricidia sepium contra cuatros bacterias patogénicas: Pseudomonas aeruginosa, Escherichia coli, Klebsiella pneumoniae y Staphylococcus aureus. Donde Pseudomonas aeruginosa fue la cepa más afectada por la actividad antagónica de todos los extractos evaluados, seguido por E. coli y $S$. aureus. Encontramos que $S$. trilobata fue la planta con mayor actividad. Realizamos pruebas mezclando extractos $(1: 1)$ de diferentes partes de cada planta donde hubo actividad antagonista y sinergista. Estos resultados son muy prometedores, ya que estas bacterias son muy estudiadas en la actualidad por sus mecanismos de alta resistencia a una amplia variedad de antibióticos.
\end{abstract}

PALABRAS ClaVES

antimicrobiano, Gliricidia sepium, Sphagneticola trilobata, Lippia graveolens, efecto inhibitorio.

\section{INTRODUCTION}

Infections caused by microorganisms represent a major public health problem with great economic repercussions. Despite advances in medicine, microorganisms have found different strategies to evade antibiotic drugs, such as the development of resistance, which limits useful therapeutic options on the market. Currently, we do not have enough pharmaceutical products to meet the therapeutic needs of the population (Prestinaci et al. 2015). Resistance of microbial pathogens to antimicrobial drugs is rapidly increasing worldwide, this has spread the use of combination therapy, consisting of the use of more than one antibiotic per treatment that increases toxicity associated with drug side effects. This situation could be more dangerous when it comes to immune suppressed patients (Fair \& Tor, 2014). 
Unfortunately, the discovery of new compounds for the treatment of human diseases and their development is a long and expensive process. This makes difficult to study all the plants used in traditional medicine, but many of them contain compounds that could become useful drugs for therapeutic and for this reason, scientists are still interested in medicinal plant study. The plants chosen for the present study were selected based on their wide use in traditional medicine. Sphagneticola trilobata is used to treat hyperglycemia, dysmenorrhea, cough, allopathic skin diseases and abdominal pain, some of these biological effects have been supported by scientific studies (Kade et al. 2010; Flores \& Quinlan, 2014; Rahman, 2015). Additionally, in other countries it has also been determined their antimicrobial activity (Taddei and Rosas Romero, 1999; Utrakoon et al. 2009; Govindappa et al. 2011; Chethan et al. 2012; Toppo et al. 2013). Gliricidia sepium is used to control fever, muscle pain, and gonorrhea. In Mexico, it is employed as an antipyretic, expectorant and diuretic (Survase \& Raut, 2011; Nadhi et al. 2016). The extracts of this plant have also displayed potent antimicrobial activity (Nazli et al. 2008; Abulude \& Adebote, 2009; Jose \& Reddy, 2010; Nazli et al. 2011; Sukumar \& Aparna, 2012; Akharaiyi, Boboye \& Adetuyi, 2012; S Kumar \& Simon, 2016; Oladunmoye et al., 2018). Finally, Lippia graveolens is widely used to treat diarrhea, vomiting, indigestion, dysentery and as antiviral, antiparasitic, nematicidal and antimicrobial (Argueta et al., 1994; Monroy \& Castillo 2000; Salgueiro, 2003; López-Aroche et al. 2008; Pilau et al. 2011; Molina-Garza, 2014; Miller et al. 2015).

This research aims to determine the antimicrobial activity of $L$. graveolens, S. trilobata and G. sepium, highlighting its antimicrobial properties against multiresistant bacteria. Escherichia coli is one of the most common bacteria provoking intestinal tract infections and neonatal meningitis (Pouillot et al. 2012). Klebsiella pneumoniae produces very severe pneumonia (Jondle et al. 2018). Pseudomonas aureginosa causes urinary tract infections that could become systemic in many cases (Mittal et al. 2009). Staphylococcus aureus infects wounds and can cause septicemia, endocarditis, and toxic shock syndrome (Lin et al. 2010). These bacterial strains can present early resistance to all antibiotics used to date, including B-lactams and carbapenems. According to the World Health Organization (WHO), among the multiresistant strains with priority for the search and development of new antibiotics, the species $P$. aeruginosa, K. pneumoniae and E. coli are in Martínez., R.J. \& Colaboradores 
the Critical Category and S. aureus is in the High-priority Category (Tacconelli et al. 2018).

Infinity of tests are carried out in search of the compound that contains an efficient antimicrobial activity. The synergy of the extract mixture could be an alternative strategy, to add to the different experiments, and therapeutics that exist. Toxicity assessment of such mixtures can be useful, and these interactions could be beneficial for the control of diseases produced by microorganisms. (Enke et al. 2011; Caesar \& Cech, 2019). In this context of constant "arms race between bacteria and man", new drugs are urgently needed that could come from compounds found in plants that live in tropical forests.

\section{METHODS}

\section{Collection of plants and extracts preparation.}

The plants used in this study (Lippia graveolens, Sphagneticola trilobata and Gliricidia sepium) were collected in Altos de María, Panama Oeste, Panama and identified in the Herbarium of the University of Panama. The harvested plants were washed with water, disinfected, rinsed with distilled water, and finally dried in the shade at room temperature. The aerial parts (leaves and stems) of the plants were separated and washed again and then dried for seven days at $25^{\circ} \mathrm{C}$. Once dried, the material was triturated with a blender and placed in methanol for 48 hours, the solvent was decanted and filtered, then evaporated on a rotary evaporator, then on a vacuum pump to obtain the crude extract.

\section{Biological evaluation \\ Bacterial Strains}

Eschericia coli CECT434, Klebsiella pneuminae ATCC11296, Pseudomona aeruginosa CECT907, and Sthaphylococcus aureus ATCC25923 were used to test the antibacterial activity of the methanolic extracts.

\section{Antibacterial Bioassays}

Two mg of each extract were dissolved in DMSO and antimicrobial activity was tested using the Bauer \& Kirby agar diffusion assay (Woods \& Washington, 1995). Bacterial inoculum was prepared at a concentration equal to $0.5 \mathrm{McFarland}$ turbidity standard, $100 \mathrm{ml}$ of inoculum was applied to the surface of a trypticase and soy agar plate at 
a $\mathrm{pH}$ between 7.2 and 7.4. Then, the disks impregnated with the extract of each plant [concentration $(0.04 \mathrm{mg} / \mathrm{uL})$ ] were placed on the surface of the culture medium. Petri dishes with a diameter of $145 \mathrm{~mm}$ were used and a maximum of eight discs were placed in each plate. Three replications were made for each microorganism. Subsequently, the plates were incubated at $37{ }^{\circ} \mathrm{C}$ for 24 hours. Each Petri dish was observed with indirect light and each inhibition zone was measured using a previously correctly graduated caliper. The mean of the halo of four replications is expressed in Table 1.

\section{Combination of Extracts}

One mg of each crude extract from different parts of the plants, were mixed (1:1) and resuspended in $100 \mathrm{uL}$ of DMSO to homogenize it and create an homogeneous solution in the order mentioned in Table 2. Bioassays were performed using the methodology explained above.

\begin{tabular}{|c|c|c|c|c|c|c|c|c|}
\hline \multirow[b]{3}{*}{ Bacteria } & \multicolumn{6}{|c|}{ Extracts } & \multirow{3}{*}{$\begin{array}{c}\text { Controls } \\
\text { CP }\end{array}$} & \multirow[b]{3}{*}{$\mathrm{CN}$} \\
\hline & \multicolumn{3}{|c|}{ Leaves } & \multicolumn{3}{|c|}{ Stems } & & \\
\hline & LG & ST & GS & LG & ST & GS & & \\
\hline S. aureus & - & $14.6 \pm 0.6$ & - & - & $12.5 \pm 0.9$ & $13.5 \pm 0.9$ & $46 \pm 2.6$ & - \\
\hline P. aeruginosa & $14.5 \pm 1.3$ & $14.5 \pm 0.6$ & $14.5 \pm 0.5$ & $16 \pm 1$ & $16.8 \pm 0.3$ & $16 \pm 1$ & $21 \pm 1$ & - \\
\hline E. coli & $18 \pm 1.7$ & $18.5 \pm 0.5$ & - & $15.5 \pm 0.9$ & $18 \pm 1$ & - & $28 \pm 2.6$ & - \\
\hline K. pneumoniae & - & - & - & - & - & - & $31 \pm 1.7$ & - \\
\hline
\end{tabular}

Table 1: Antibacterial activity (diameter of the inhibition zone in $\mathrm{mm}$ ) of the methanol extracts $(0.04 \mathrm{mg} / \mu \mathrm{Lin}$ DMSO) from stems and leaves of evaluated plants against gram negative and gram-positive bacteria using agar diffusion discs assay. Plants: LG: Lippia graveolens, ST: Sphagneticola trilobata and GS: Gliricidia sepium. CP. Positive control (Trimethoprim with sulfa $10 \mu \mathrm{g} / \mathrm{mL}$ ), CN: Negative control (DMSO).

\begin{tabular}{|c|c|c|c|c|c|c|c|c|c|c|c|c|c|c|c|c|c|}
\hline \multirow[b]{2}{*}{ Bacteria } & \multicolumn{15}{|c|}{ Extract } & \multicolumn{2}{|l|}{ Control } \\
\hline & $\begin{array}{c}1 \\
\mathrm{Lgl}+\mathrm{Stl}\end{array}$ & $\begin{array}{c}2 \\
\mathrm{Lgl+Gsl}\end{array}$ & $\begin{array}{c}3 \\
\text { Lgl+Lgs }\end{array}$ & $\begin{array}{c}4 \\
\mathrm{Lgl+Sts}\end{array}$ & $\begin{array}{c}5 \\
\text { Lgl+Gss }\end{array}$ & $\begin{array}{c}6 \\
\text { Stl+Gs1 }\end{array}$ & $\begin{array}{c}7 \\
\text { Stt+Lgs }\end{array}$ & $\begin{array}{c}8 \\
\text { St1+Sts }\end{array}$ & $\begin{array}{c}9 \\
\text { St1+Gss }\end{array}$ & $\begin{array}{c}10 \\
\text { Gsl+Lgs }\end{array}$ & $\begin{array}{c}11 \\
\text { Gst+Sts }\end{array}$ & $\begin{array}{c}12 \\
\text { Gsl+Gss }\end{array}$ & $\begin{array}{c}13 \\
\text { Lgs +Sts }\end{array}$ & $\begin{array}{c}14 \\
\text { Lgs+Gss }\end{array}$ & $\begin{array}{c}15 \\
\text { Sts+Gss }\end{array}$ & CP & $\mathrm{CN}$ \\
\hline S. aureus & - & - & - & - & - & - & - & $21 \pm 0.7$ & - & - & $17 \pm 0.7$ & $21 \pm 0.7$ & - & - & $19 \pm 0.7$ & $40 \pm 1.0$ & 5 \\
\hline P. aeruginosa & - & - & - & - & - & - & - & - & - & - & $18 \pm 0.0$ & - & - & - & - & $15 \pm 1.0$ & \\
\hline E. coli & $16 \pm 0.0$ & $17 \pm 0.7$ & $15 \pm 0.7$ & $17 \pm 0.7$ & - & - & - & - & - & - & - & - & - & - & - & $22 \pm 0.5$ & \\
\hline K. pneumoniae & - & - & - & - & - & - & - & - & - & - & - & - & - & - & - & $25 \pm 0.5$ & \\
\hline
\end{tabular}

Table 2. Antimicrobial effect for the combination of different methanol extracts (all values in mm). Extract mix: (1) Leaves of $L$. graveolens and S. trilobata; (2) Leaves of $L$. graveolens and G. sepium; (3) Leave and stem of $L$. graveolens; (4) Leave of L. graveolens and stem S. trilobata; (5) Leave of L. graveolens and stem G. sepium; (6) Leaves of S. trilobata and G. sepium; (7) Leave of S. trilobata and stem L. graveolens; (8) Leave and stem of $S$. trilobata; $(9)$ Lilove of $S$. trilobata and stem of $G$. sepium; (10) Leve of $G$. sepium and stem of $L$ graveolens; Lrilobata; (9) Leave of $S$. trilobata and s. trilobata; (12) Leaves (10) Leave of $G$. sepium and (13) Stems of $L$. graveolens (11) Leave of G. sepium and stems of S. trilobata; (12) Leaves and stems of G. sepium; (13) Stems of L. graveolens and
S. trilobata; (14) Stems of L. graveolens and G. sepium; (15) Stems of S. trilobata and G. sepium. 


\section{RESULTS AND DISCUSSION}

The antibacterial activity of leaves and stems extracts of each plant are summarized in Table 1. Methanolic extracts from leaves and stems of $L$. graveolens were positive against $P$. aeruginosa and E. coli. Essential oils of $L$. graveolens have been tested against Streptococcus faecalis, $P$. vulgaris, S. aureus; S. epidermidis, B. subtilis, Sarcina lutea, S. boydii, Vibrio cholerae, E. coli, Micrococcus luteus, Enterobacter agglomerans, E. aerogenes; Y. enterocolitica, S. typhi and Enterococcus $s p$ (Salgueiro et al. 2003; Hernandez et al. 2009; Hernández-Hernández et al. 2014; Castellanos-Hernández et al. 2020). Essential oils of $L$. graveolens have phenolic monoterpenoids (e.g., carvacrol, $\alpha$-terpinyl acetate, $m$-cymene, thymol and $\beta$-pinene) with antiparasitic, antifungal, antiviral and antimicrobial activity (Kintzios 2002; Salgueiro et al. 2003; Hernandez et al. 2009; Quintanilla-Licea et al., 2020; Salgueiro et al. 2003; Hernández et al. 2008; Pilau et al. 2011). However, this is the first time that methanolic extracts of leaves and stems of $L$. graveolens are tested against the gram-negative bacteria $P$. aeruginosa and E. coli. Methanol extracts of leaves and stems of S. trilobata has antimicrobial activity against $S$. aureus, $P$. aeruginosa and E. coli with a mean inhibition zone of $14.6 \pm 0.6$ and $18.5 \pm 0.5$ respectively. Studies by Toppo et al. (2013) found antibacterial activity in methanolic extracts of $S$. trilobata leaves against $S$. aureus, S. typhi and P. aeruginosa and the methanolic extracts from stems has antimicrobial activity against $S$. aureus. Apparently, this is the first report of an antibacterial activity of leaves and stems of $S$. trilobata against $P$. aeruginosa and E. coli. Similar antibacterial activity with methanolic extracts of $S$. trilobata have been found against Bacillus subtilis, Mycobacterium smegmatis, $S$. aureus, S. epidermidis, E. coli, Proteus vulgaris, P. aeruginosa, Salmonella paratyphi and Shigella sonnei (Taddi et al. 1999). Ethanolic extracts of leaves and stems of $S$. trilobata have shown antimicrobial activity against $P$. aeruginosa, $S$. aureus, $K$. pneumoniae, Xanthomonas oryzae and $X$. axanopodis (Govindappa et al. 2011). S. trilobata shows the most promising results since extracts from its leaves and stems show activity against three of the four multi-drug resistant bacteria evaluated in this study.

In the same way, leaves methanolic extracts of G. sepium showed a mean zone of inhibition against $P$. aeruginosa of $14.5 \mathrm{~mm}$ and methanolic extracts of stems had activity against $S$. aureus and $P$. aeruginosa with inhibition zones of $13.5 \mathrm{~mm}$ and $16 \mathrm{~mm}$, respectively. 
In this study $K$. pneumoniae presented resistance to all methanolic extracts tested as was found by Jhon et al. (2006), Abulude and Adebote (2009) and Nazli et al. (2011). A positive antimicrobial activity result was also found with leaves of G. sepium against $S$. aureus and E. coli as was reported by Akharaiyi et al. (2012) and Oladunmoye (2018). However, information about antimicrobial activity of stems is limited. These results showed that $G$. sepium have a good antimicrobial activity against two of the resistant bacteria tested here.

Regarding the susceptibility of the pathogenic bacteria analyzed, $P$. aureginosa was the most inhibited strain by most of the evaluated extracts, followed by $E$. coli and $S$. aureus. This suggests that our results are promising, as these bacteria are currently studied for their extended multidrug resistance.

When comparing the activity of extracts from leaves versus extract from stems to analyze if there is a significant difference between the antimicrobial activity of the organs that integrate the aerial parts of each plant, we found that stem extracts displayed a greater inhibition halo than leaf extracts, this fact was similar for the three evaluated plant species. In fact, the inhibition halos showed by the evaluated extracts were greater than $10 \mathrm{~mm}$, which makes them very promising since all extracts displayed an inhibition zone equal to or greater than $50 \%$ of the inhibition presented by the positive control, which is a pure compound.

Table 2 shows the synergism of the extract mixture 1, 2, 3, 4 against $E$. coli; 8, 11, 12 and 15 against $S$. aureus; and 11 against $P$. aeruginosa. It can be noted that not all the extracts were synergistic. Many mixtures of the extracts were antagonistic. It cannot be demonstrated why antagonism or synergism occurs due to the number of compounds in the samples (Enke et al. 2011). These findings are interesting for future studies, since their metabolites vary in plants, according to the soil where they are cultivated, the region of origin, temperatures, and other environmental factors (Khan, 2006).

The results obtained corroborate the antimicrobial potential that the three plants evaluated have shown in previous works. S. trilobata is the species with the greatest potential against three of the four evaluated 
bacterial strains. Furthermore, we found that stem extracts are more active than leave extracts, except for extracts evaluated against E. coli, where the leave extracts showed greater activity. Regarding efficacy, our study provides additional scientific evidence that the evaluated plants can still be considered by the human population as an alternative remedy to combat bacterial infections. It is also important to note that studies related toxicity are necessary to promote the safe use of these three plants.

\section{ACKNOWLEDGMENT}

To the Laboratory of Biological Studies of Arthropods, University of Panama and to Dr. Dora I. Quirós and Dr. Daniel Emmen for their support and space provided to carry out this research. The authors thank the Vicerrectoría de Investigación y Postgrado, Universidad de Panamá for the financial support (Project CEIP-01-04-20-2018-01).

\section{REFERENCES}

Abulude, F. O., \& Adebote V. T. 2009. Antibacterial Investigation of Crude Extracts of the Root Bark of Gliricidia Sepium. Continental Journal of Microbiology, 3, 23-26.

Akharaiyi, F., Boboye, B., \& Adetuyi, F. 2012. Antibacterial, Phytochemical and Antioxidant Activities of the Leaf Extracts of Gliricidia sepium and Spathodea campanulata. World Applied Sciences Journal, 16:4, 523-530.

Argueta, A., Cano, L., Rodarte, M. 1994. Atlas de las Plantas de la Medicina Tradicional Mexicana. Instituto Nacional Indigenista, 1:3, 861087.

Castellanos-Hernández, O. A., Rodríguez-Sahagún, M. D., AcevedoHernández, G. J., Rayn, C. A., \& Rodríguez-Sahagún, A. 2020. EVALUACIÓN ANTIMICROBIANA DEL ACEITE ESENCIAL DE Lippia graveolens COMO INHIBIDOR DE CRECIMIENTO DE Salmonella sp, E. coli Y Enterococcus sp. e-CUCBA, 14, 1-6.

Caesar, L. K., \& Cech, N. B. 2019. Synergy and antagonism in natural product extracts: when $1+1$ does not equal 2. Natural product reports, 36:6, 869-888. 
Chethan, J., Kumara, K. K. S., Niranjana, S. R., \& Prakash, H. S. 2012. Evaluation of antioxidant and antibacterial activities of methanolic flower extract of Wedelia trilobata (L.) Hitch. African Journal of Biotechnology. 11:41, 9829-9834.

Enke, C. G., \& Nagels, L. J. 2011. Undetected components in natural mixtures: how many? What concentrations? Do they account for chemical noise? What is needed to detect them?. Analytical chemistry, 83(7), 2539-2546.

Fair, R. J., \& Tor, Y. 2014. Antibiotics and bacterial resistance in the $21 \mathrm{st}$ century. Perspectives in medicinal chemistry, 6, PMC-S14459.

Flores, K. E., \& Quinlan, M. B. 2014. Ethnomedicine of menstruation in rural Dominica, West Indies. Journal of Ethnopharmacology, 153:3, 624-634.

Govindappa, M., Naga Sravya, S., Poojashri, M. N., Sadananda, T. S., Chandrappa, C. P., Santoyo, G., Anil Kumar, N. V. 2011. Antimicrobial, antioxidant and in vitro anti-inflammatory activity and phytochemical screening of water extract of Wedelia trilobata (L.) hitchc. Journal of Medicinal Plant Research, 5:24, 5718-5729.

Hernández, T., Canales, M., García, A. M., Duran, Á., Meráz, S., Dávila, P., \& Ávila, J. G. 2008. Antifungal activity of the essential oils of two Verbenaceae: Lantana achyranthifolia and Lippia graveolens of Zapotitlan de las Salinas, Puebla (Mexico). Boletín Latinoamericano y del Caribe de Plantas Medicinales y Aromáticas, 7: 4, 202-206.

Hernandez, T., Canales, M., Avila, J. G., García, A. M., Meraz, S., Caballero, J., \& Rafael, L. I. R. A. 2009. Composition and antibacterial activity of essential oil of Lippia graveolens HBK (Verbenaceae). Boletín Latinoamericano $y$ del Caribe de Plantas Medicinales $y$ Aromáticas, 8:4, 295-300.

Hernández-Hernández, E., Regalado-González, C., VázquezLandaverde, P., Guerrero-Legarreta, I., \& García-Almendárez, B. E. 2014. Microencapsulation, chemical characterization, and antimicrobial activity of Mexican (Lippia graveolens HBK) and European (Origanum vulgare L.) oregano essential oils. The Scientific World Journal, 2014. 
Jhon, J.R., Veronica, J.O., Soul, A.O., \& John, F.M. 2006. Screening for antibacterial activity of ten medicinal plants used in Colombia folkloric medicine: a possible alternative in the treatment of non somial infection. BMC Complementary and Alternative Medicine, 10, 1186-1472.

Jondle, C.N., Gupta, K., Mishra B.B., Sharma J. 2018. Klebsiella pneumoniae infection of murine neutrophils impairs their efferocytic clearance by modulating cell death machinery. PLoS Pathogens, 14:10, e1007338.

Jose, B., \& Reddy, L. 2010. Evaluation OF Antibacterial Activity of the leaf and flower essential oils of Gliricidia sepium from South India. International Journal of Applied Pharmaceutics, 2:2, 20-22.

Kade, I. J., Barbosa, N. B. V., Ibukun, E. O., Igbakin, A. P., Nogueira, C. W \& Rocha, J. B. T. 2010. Aqueous extracts of Sphagneticola trilobata attenuates streptozotocin-induced hyperglycaemia in rat models by modulating oxidative stress parameters. Biology and Medicine, 2, 1-13.

Kakuko, Y. Fumiko, A. Ogayama, A. N. Hikaru, O. Lucio, L. P. Edith, L. Elizabeth, M. Abigail, A., \& Ricardo, R.C. 2005. Antibacterial activity of crude extract from Mexican medicinal plants and purified coumarins and xanthones Journal of Ethnopharmacology, 97:2, 293299

Khan, I. A. 2006. Issues related to botanicals. Life sciences, 78:18, 2033-2038.

Kintzios, S. E. 2002. Oregano. In The genera Origanum and Lippia. London, UK: Taylor \& Francis.

López-Aroche, U., Salinas-Sánchez, D. O., de Gives, P. M., LópezArellano, M. E., Liébano-Hernández, E., Valladares-Cisneros, G., \& Hernández-Velázquez, V. 2008. In vitro nematicidal effects of medicinal plants from the Sierra de Huautla, Biosphere Reserve, Morelos, Mexico against Haemonchus contortus infective larvae. Journal of helminthology, 82:1, 25-31.

Lin, Y. C., \& Peterson, M. L. 2010. New insights into the prevention of 
staphylococcal infections and toxic shock syndrome. Expert review of clinical pharmacology, 3:6, 753-767.

Miller, A. B., Cates, R. G., Lawrence, M., Soria, J. A. F., Espinoza, L. V., Martinez, J. V., \& Arbizú, D. A. 2015. The antibacterial and antifungal activity of essential oils extracted from Guatemalan medicinal plants. Pharmaceutical biology, 53:4, 548-554.

Mittal, R., Aggarwal, S., Sharma, S., Chhibber, S., \& Harjai, K. 2009. Urinary tract infections caused by Pseudomonas aeruginosa: a minireview. Journal of infection and public health, 2:3, 101-111.

Molina-Garza, Z. J., Bazaldúa-Rodríguez, A. F., Quintanilla-Licea, R., \& Galaviz-Silva, L. 2014. Anti-Trypanosoma cruzi activity of 10 medicinal plants used in northeast Mexico. Acta tropica, 136, 14-18.

Monroy, C., Castillo, P., 2000. Plantas Medicinales Utilizadas en el Estado de Morelos, Centro de Investigaciones Biológicas. UAEM. 89298.

Nahdi, M. S., Martiwi, I. K. A., \& Arsyah, D. C. 2016. The ethnobotany of medicinal plants in supporting the family health in Turgo, Yogyakarta, Indonesia. Biodiversitas, 17:2, 900-906.

Nazli, R., Akhter, M., Ambreen, S., Hameed Solangi, A., \& Solangi, H. 2008. Insecticidal, nematicidal and antibacterial activities of Gliricidia Sepium. Pakistan Journal of Botany, 40:6, 2625-2629.

Nazli, R., Sohail, T., Nawab, B., \& Yaqeen, Z. 2011. Antimicrobial property of gliricidia sepium plant extract. Pakistan Journal of Agricultural Research, 24:1-4, 51-55.

Oladunmoye, M. K., J. Ayantola, K., A. Agboola, A., M. Olowe, B., \& G. Adefemi, O. 2018. Antibacterial and Ftir Spectral Analysis of Methanolic Extract of Gliricidia sepium Leaves. Journal of Advances in Microbiology, 9:4, 1-10.

Pilau, M. R., Alves, S. H., Weiblen, R., Arenhart, S., Cueto, A. P., \& Lovato, L. T. 2011. Antiviral activity of the Lippia graveolens (Mexican oregano) essential oil and its main compound carvacrol against human Martinez, R.J. \& Colaboradores 
and animal viruses. Brazilian Journal of Microbiology, 42:4, 16161624.

Pouillot F., Chomton M., Blois H., Courroux C., Noelig J., Bidet P., Bingen E., Bonacorsi S. 2012. Efficacy of bacteriophage therapy in experimental sepsis and meningitis caused by a clone O25b:H4-ST131 Escherichia coli strain producing CTX-M-15. Antimicrobial Agents and Chemotherapy; 56, 3568-3575.

Prestinaci, F., Pezzotti, P., \& Pantosti, A. 2015. Antimicrobial resistance: a global multifaceted phenomenon. Pathogens and global health, 109(7), 309-318.

Rahman, A. H. M. M. 2015. Ethnomedicinal survey of angiosperm plants used by Santal tribe of Joypurhat District, Bangladesh. International Journal of Advanced Research, 3:5, 990-1001.

S Kumar, N., \& Simon, N. 2016. Antibacterial and Phytochemical Activity of Gliricidia sepium against Poultry Pathogens. Journal of Pharmacognosy and Phytochemistry, 5:2, pp.131-133.

Salgueiro, L. R., Cavaleiro, C., Gonçalves, M. J., \& da Cunha, A. P. 2003. Antimicrobial activity and chemical composition of the essential oil of Lippia graveolens from Guatemala. Planta Medica, 69:1, 80-83.

Sukumar, D., \& Aparna, C. 2012. Phytochemical Studies and Antibacterial Investigations on Gliricidia Sepium. Paripex - Indian Journal of Research, 3:1, 12-13.

Survase, S. A., \& Raut, S. D. 2011. Ethnobotanical study of some tree medicinal plants in Marathwada, Maharashtra. Journal of Ecobiotechnology, 3:2, 17-2.

Taddei, A., \& Rosas-Romero, A. J. 1999. Antimicrobial activity of Wedelia trilobata crude extracts. Phytomedicine, 6, 133-134.

Tacconelli, E., Carrara, E., Savoldi A.. et al. 2018. Discovery, research, and development of new antibiotics: the WHO priority list of antibioticresistant bacteria and tuberculosis. The Lancet Infectious Diseases, 18:3, 


\section{$318-327$.}

Toppo, K. I., Gupta, S. H. U. B. H. A., Karkun, D. E. E. P. A. K., Agrawal, S., \& Kumar, A. N. I. L. 2013. Antimicrobial activity of Sphagneticola trilobata (L.) Pruski, against some human pathogenic bacteria and fungi. The Bioscan, 8:2, 695-700.

Utrakoon, S., Photchanachai, S., Laohakunjit, N., \& Vichitsoonthonkul, T. 2009. Efficacy of essential oil extracted of Wedelia trilobata (L.) leaves on the growth of Aspergillus flavus. Agricultural Sciences Journals, 40:1, 121-124.

Woods, G., \& Washington, J. 1995. Antibacterial Susceptibility Tests: Dilution and Disk Diffusion Methods. In Manual of Clinical Microbiology. Sixth edition. Eds: Murray P., Baron E., Pfaller M. et al.: American Society of Microbiology, Washington D.C.

Recibido el 20 agosto, y aceptado el 11 diciembre 2020. 